\title{
Satisfaction study of the teaching-learning process of students close to graduating from the Bachelor of Dental surgeon
}

\section{Estudio de satisfacción del proceso de enseñanza-aprendizaje de los alumnos próximos a egresar de la Licenciatura en Cirujano dentista}

\author{
MORENO-MARIN, Flora†*, ROESCH-RAMOS, Laura, MORA-SANCHEZ, Aura Leonora and \\ MANTILLA-RUIZ, Manuel
}

Universidad Veracruzana, Faculty of Dentistry, Veracruz Region. Mexico.

ID $1^{\text {st }}$ Author: Flora, Moreno-Marin / ORC ID: 0000-0003-0080-2364, CVU CONACYT ID: 421753

ID $1^{\text {st }}$ Co-author: Laura, Roesch-Ramos / ORC ID: 0000-0003-0188-797X, Researcher ID Thomson: Q-8349-2016, CVU CONACYT ID: 324897

ID $2^{\text {nd }}$ Co-author: Aura Leonora, Mora-Sánchez / ORC ID: 0000-0002-6356-7720, CVU CONACYT ID: 321805

ID $3^{\text {rd }}$ Co-author: Manuel, Mantilla-Ruiz / CVU CONACYT ID: 421989

DOI: $10.35429 / J E H W .2020 .6 .4 .32 .34$

Received January 25, 2020; Accepted June 30, 2020

\begin{abstract}
The growing technological innovations, the claim of society that demands increasingly efficient services and the strong competition between educational institutions, forces them to offer increasingly better options especially in the field of health; In this context, the Universidad Veracruzana has assumed the task of implementing strategies to carry out an exhaustive analysis of the satisfaction of the students who are about to graduate from the Bachelor of Dental Surgeon. Objective: To know the level of satisfaction of students with respect to their Bachelor of Dental Surgeon upon graduation. Methodology: The Student Satisfaction Questionnaire was carried out with eight chapters; it consists of 11 dimensions and 104 items. The instrument used was designed based on the specifications of the National Association of Universities and Institutions of Higher Education ANUIES and was adapted to the information needs about students close to graduation, the respondents were kept anonymous to avoid bias. The students close to graduating from the Bachelor of Dental Surgeon at the UV are $31 \%$ satisfied, $54 \%$ between satisfied, quiet and very satisfied; for the poorly satisfied and dissatisfied indicators, only $12 \%$ was counted. Contribution: The educational program is socially relevant.
\end{abstract}

Satisfaction, Teaching-learning process, Dental surgeon

\section{Resumen}

Las crecientes innovaciones tecnológicas, el reclamo de la sociedad que demanda servicios cada vez más eficientes y la fuerte competencia entre las Instituciones educativas, obliga a las mismas a brindar cada vez mejores opciones especialmente en el campo de la salud; en ese contexto la Universidad Veracruzana se ha abocado a la tarea de implementar estrategias para realizar un análisis exhaustivo de la satisfacción de los estudiantes próximos a egresar de la Licenciatura en Cirujano Dentista. Objetivo: Conocer el nivel de satisfacción de los estudiantes sobre su Licenciatura de Cirujano Dentista a su egreso. Metodología: SE realizó el Cuestionario de satisfacción del estudiante con ocho capítulos, consta de 11 dimensiones y 104 reactivos. El instrumento utilizado fue diseñado en base a las especificaciones de la Asociación Nacional de Universidades e Instituciones de Educación Superior ANUIES, y fue adecuado a las necesidades de información acerca de los estudiantes próximos a egresar, fue en anonimato de los encuestados para evitar sesgos. Los estudiantes próximos para egresar de la Licenciatura de Cirujano Dentista UV se encuentran satisfechos el $31 \%$, el $54 \%$ entre satisfecho y bastante y el muy satisfecho; para los indicadores poco satisfecho e insatisfecho únicamente se contó con el $12 \%$. Contribución: El programa educativo es socialmente pertinente.

Satisfacción, Proceso enseñanza-aprendizaje, Cirujano dentista

Citation: MORENO-MARIN, Flora, ROESCH-RAMOS, Laura, MORA-SANCHEZ, Aura Leonora and MANTILLARUIZ, Manuel. Satisfaction study of the teaching-learning process of students close to graduating from the Bachelor of Dental surgeon. Journal-Health Education and Welfare. 2020. 4-6:32-34.

\footnotetext{
* Correspondence to Author (Email: flmoreno@uv.mx)

$\dagger$ Researcher contributing as first author.
} 


\section{Introduction}

In the Universidad Veracruzana studies are frequently carried out to find out and know the opinion of the students regarding their teachinglearning process as well as their different opinions about the educational, academic and learning experiences.

Recent technological innovations, the claim of society that increasingly demands more efficient services and the opening of different educational institutions that offer the degree of dental surgeon in Veracruz, has forced to become more and more efficient, to provide better options especially in the field of oral health and under this context the Faculty of Dentistry of the Universidad Veracruzana has undertaken the task of implementing different strategies to make the teaching-learning process in its students better and better.

The Faculty of Dentistry has simulation areas for the different dental practices in the areas of oral rehabilitation, pediatric dentistry and different simulators such as X-rays and anesthesia. These simulators allow students to carry out practices in front of an artificial individual that enables students to become competent in the different practices before working with a patient, which gives them the security and knowledge necessary to be able to correctly carry out their interventions in the population.

The Universidad Veracruzana, through HED (higher education department) Health Sciences, has undertaken the task of implementing strategies for, based on a strict self-evaluation, the convening of a meeting between graduates and employers, specifically of students who are about to graduate from the Faculty of Dentistry Campus Boca del Río and an exhaustive analysis of both the academic content, the educational relevance in the environment of the region, the perception of the students who are about to leave and the graduates themselves, raise educational performance in all academic aspects of the institution, one of them is the conformation of the Organizing Commission of the 1st. Forum of Graduates and Employers, likewise within the framework of the same Forum, carry out studies of student and graduate satisfaction, in addition to obtaining the valuable opinion of employers.
It is important to know the perception of students about to graduate about their academic trajectory.

\section{Objective}

To know the level of satisfaction of the students regarding their Degree in Dental Surgeon upon graduation. All of the above, in order to carry out the actions that lead to exceeding the performance of both the Institutions and the students and graduates, one of the fundamental tools will be this study that will precisely be called "Student Satisfaction Study" which is Institutionally applied in all the degrees offered.

\section{Methodology}

In the study of student satisfaction, the scope of the study, the objectives and the importance of their answers are explained to the students, since through this study the Faculty of Dentistry will be able to determine if the students are satisfied with the teaching-learning process carried out during their undergraduate degree.

The instrumentation used, the methodology to determine the confidence levels in relation to the sample size and, in the next chapter, the stages of data collection are detailed. The questionnaires were provided by the Organizing Committee of the 1st. Forum of Graduates and Employers 2011, which meet the specifications suggested by the Association of Universities and Institutions of Higher Education (ANUIES) and endorsed by the Central Graduate Monitoring Module of the Institutional Planning Directorate of the Veracruzana University and was adequate to the information needs about the students about to graduate, it was anonymous by the respondents to avoid bias.

The work was aimed at students close to graduating from the Boca del Río Campus Dentistry Faculty, in order to carry out an analysis of the satisfaction of the student who is about to graduate in 2020, most of whom were admitted in 2013.

Student satisfaction questionnaire with eight chapters, consisting of 11 dimensions and 104 items. Within the questionnaire in the teaching-learning process section which is the one studied in this study. 


\section{Results}

Students close to graduating from the UV Dental Surgeon Degree are 31\% satisfied, 54\% between satisfied and quite and very satisfied; for the poorly satisfied and unsatisfied indicators, only $12 \%$ were counted, which makes the educational program socially relevant.

In addition to the questioning about the teaching-learning process, the general satisfaction with the study plan was also questioned. Graphic 1.

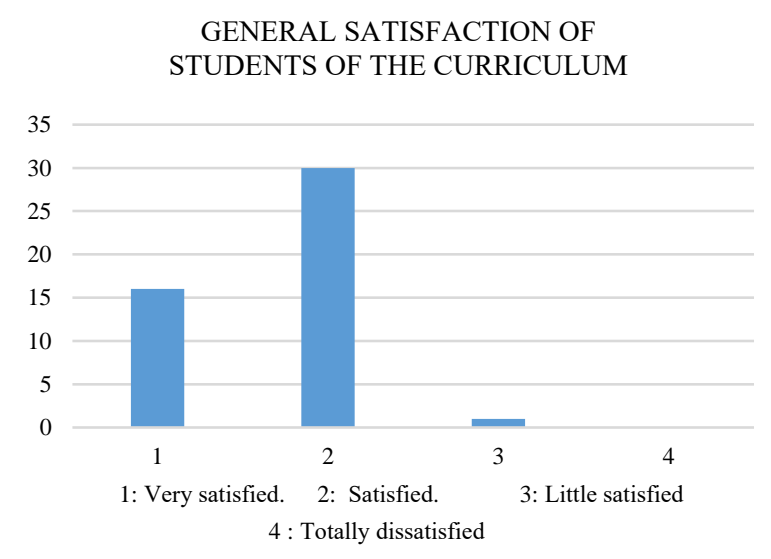

Graphic 1 General satisfaction with the curriculum

\section{Conclusions}

The contribution of this study was to carry out a self-analysis of the teaching-learning process of the Baccalaureate in Dental Surgeon and to be in a constant self-evaluation to know the existing Strengths and Areas of Opportunity. And this study determines that the Dental Surgeon educational program is socially relevant and that students nearing graduation are satisfied with having completed it.

\section{References}

Spoletti B. (2014) La enseñanza en la clínica odontológica. Revista de Educación en ciencias de la salud. 11 (2): 166-170.

Fresán Orozco, M. (2003). Esquema básico para estudios de egresados en educación superior. México: ANIUES.
Garduño, L., \& Flores, A. (2010). Estudio de la satisfacción del estudiante como indicador de la calidad de la enseñanza en las escuelas normales del Estado de Puebla. Recuperado el 05 de Junio de 2015, de COMIE: http://www.comie.org.mx/congreso/memoriaele ctronica/v09/ponencias/at01/PRE1180989880.p df

UDG. (2008). Metodología para el estudio de satisfacción de estudiantes y egresados. México: PRODEs.

Mohiuddin, K., Islam, MA, Sharif, M., Nur, S., Talukder, M. y Alghobiri, MA (2020). Enumeración de posibles métodos de enseñanza en la educación superior: un estudio interdisciplinario. Internacional de Investigaciones en Educación, 2020.
MORENO-MARIN, Flora, ROESCH-RAMOS, Laura, MORASANCHEZ, Aura Leonora and MANTILLA-RUIZ, Manuel. Satisfaction study of the teaching-learning process of students close to graduating from the Bachelor of Dental surgeon. Journal-Health Education and Welfare. 2020 